\title{
DIRECT ETHOXYLATION OF GLYCEROL MONO OLEATE FROM PALM OIL DERIVATE AS A NOVEL NON-IONIC POLYMERIC SURFACTANT
}

\author{
Joddy Arya Laksmono*), Indri Badria Adilina, dan Egi Agustian \\ The Research Centre for Chemistry - Indonesian Institute of Sciences \\ Kawasan Puspiptek Serpong, Tangerang, Indonesia 15314, Ph. +62 21 7560929, fax. +62 217560549 \\ ${ }^{*}$ Corresponding Author: joddy_arya_laksmono@yahoo.com
}

\begin{abstract}
The work investigates ethoxylation of glycerol mono oleate (GMO) performed in the presence of an alkaline catalyst. Glycerol mono oleate applied was derivated from Indonesian palm oil. The reaction was conducted with variation of Glycerol mono oleate : ethylene oxide ratio, temperature, and catalyst concentration. Forier Transform Infra Red (FTIR) and Nuclear Magnetic Resonance (NMR) analysis showed products with degrees of ethoxylation $n=2$ and $n=3$. FTIR analysis of products gave a new peak at $1570 \mathrm{~cm}^{-1}$ supporting that $\mathrm{C}-\mathrm{O}-\mathrm{C}$ bond was formed. New peaks were also observed in ${ }^{13-} \mathrm{C}$ NMR analysis of run 2 and run 3 with chemical shift of $(\delta)$ 61.3385; 61.9108; 62.5117; 63.8566; 66.0982; 72.6127 and 61.2172; 63.2393; 65.9100; 72.5201, respectively. Glycerol mono oleate ethoxylated was yielded and could be useful for a novel non-ionic polymeric surfactant.
\end{abstract}

Keywords: ethoxylation, glycerol mono oleate, Indonesian palm oil, non-ionic polymeric surfactant

\begin{abstract}
Abstrak
Pada penelitian ini dilakukan proses etoksilasi gliserol mono oleat menggunakan katalis alkali. Gliserol mono oleat didapat dengan melakukan derivatisasi dari minyak sawit. Reaksi dilangsungkan dengan melakukan beberapa variasi perbandingan gliserol mono oleat : etilen oksida, temperatur, dan konsentrasi katalis. Berdasarkan analisa Forier Transform Infra Red (FTIR) and Nuclear Magnetic Resonance (NMR) didapatkan derajat etoksilasi $n=2$ dan $n=3$. Analisa FTIR memberikan puncak baru pada $1570 \mathrm{~cm}^{-1}$ yang menandakan bahwa terjadi pembentukkan ikatan C-O-C. Puncak baru juga terbentuk dari hasil analisa menggunakan ${ }^{13-} C-N M R$ pada proses run 2 dan 3, dengan pergeseran

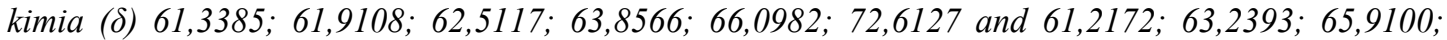
72,5201, secara berurutan. Dengan demikian, gliserol mono oleat etoksilat telah terbentuk dan dapat digunakan sebagai polimerik surfaktan non-ionik varian baru.
\end{abstract}

Kata kunci: ethoxylation, glycerol mono oleate, minyak sawit Indonesia, non-ionic polymeric surfactant

\section{INTRODUCTION}

Surface-active agents (surfactants) are used in almost any household and personal care product as well industrial process, they can acts as a detergent, emulsifier or dispersants in colloidal systems. Directly ethoxylated fatty acid methyl esters are emerging on the markets as surfactants. Taking into account the reduced production cycle of fatty acid methyl esters compred with fatty alcohols, significant cost reduction could be expected (Hreczuch, 2002).

With the advanced development of oleochemistry, surfactants from palm oil is currently an interesting issue to be investigated. Ethoxylation as one of the polymeric nonionic surfactants are produced in industry by reacting ethylene oxide with an organic molecule containing mobile hydrogen such as fatty alcohols, alkyl phenols, or fatty acids (Di Serio et al, 1994).

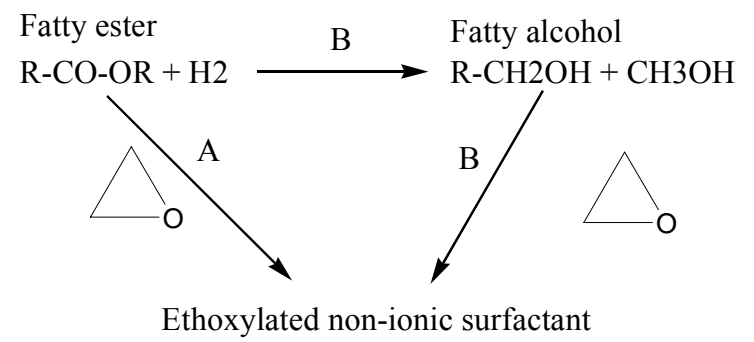

Figure 1. Direct ethoxylation from fatty ester (A) and indirect ethoxylation from fatty aklcohol (B) 
The general mechanism for ethylene oxide addition to fatty methyl ester has been described, stating that the added molecule is inserted selectively between the carbonyl carbon and methoxy group at the ester bond (Hama et al, 1997). Di Serio et al conducted ethoxylation in the liquid phase, at $150-180^{\circ} \mathrm{C}$ and $2-5$ atm, in the presence of an alkaline catalyst.

Ethoxylation produces polymeric surfactants which lengthens the hydrophilic part of the surfactant. Polymeric surfactants serve all the same functions as normal surfactants, the main difference being their greater molecular mass and higher order structural conformation. Polymeric surfactants adsorb at surfaces, either of solids to give enhanced colloidal stability, or of liquids to control foaming or emulsion stability. The choice of monomer will normally depend upon the properties required for the polymeric surfactant. Therefore, an oil soluble surfactant which stabilises an aqueous dispersed phase in an oil may be prepared by grafting hydrophobic monomers onto a water soluble substrate. For the reverse system, a water-soluble surfactant which stabilises an oil phase in water can be made by grafting hydrophilic monomers on to a hydrophobic substrate (Singh, 2006).

Surfactants are amphiphatic molecules which have a hydrophilic and hydrophobic part. Both parts have strong influence on their properties and ability to sustain stability. In this research, synthesis of polymeric surfactant was performed by direct ethoxylation, reacting ethylene oxide with glycerol mono oleate as a glyceril ester. The glycerol mono oleate were derivered from palm oil in the prescence of an alkaline catalyst. Analysis will be conducted using Fourier Transform Infrared (FTIR) and Nuclear Magnetic Resonance (NMR).

\section{EXPERIMENTAL METHOD Materials}

Fatty acid of palm oil (PT. Sumiasih, Indonesia), ethylene oxide (Sigma Aldrich, Singapore), and potassium hydroxide (E Merck) were used in the experiments. Nitrogen gas was supplied from BOC gases.

\section{Method}

\section{Ethoxylation of glycerol mono oleate}

Ethoxylation was conducted in a $600 \mathrm{~mL}$ bubble column reactor. The synthesis was performed at 120 $180^{\circ} \mathrm{C}$, with variation of $\mathrm{KOH}$ concentration. The reagent molar ratio and reaction time was kept constant at ethylene oxide: glycerol mono oleate $=1: 1$ and 5 hours. The reactor was flowed with nitrogen gas to avoid the presence of air and excess of oxygen. Glycerol mono oleate $(1 \mathrm{~mol})$ was then placed in the column and ethylene oxide $(1 \mathrm{~mol})$ was flowed into the reactor. The pressure was recorded and the reaction was performed for 5 hours. Product was collected and analyzed.

\section{Fourier Transform Infrared (FTIR) analysis}

The product was then analyzed by Fourier Transform Infrared (FTIR) spectroscopy (Shimadzu IRPrestidge-21/FTIR-8000) transmittance sampling technique. Samples were measured with spacer of $0.01 \mathrm{~mm} \sim 0.02 \mathrm{~mm}$ thickness on a KBR cell plate and then placed in the sample holder. Apodization was performed by Happ-Genzel method with number of scans: 45 , resolution: 4.0 and wavelength range: $500-4000 \mathrm{~cm}^{-1}$.

\section{Nuclear Magnetic Resonance (NMR)}

Nuclear Magnetic Resonance (JEOL, 500 $\mathrm{MHz}$ ) analysis was also performed to for structure identification. An amount of the product samples were dissolved in $\mathrm{CDCl}_{3}$ and placed in the sample holder. Proton $\left({ }^{1} \mathrm{H}\right)$, carbon $\left({ }^{13}-\mathrm{C}\right)$ analysis was measured. Glycerol mono oleate as the starting material was also analyzed and compared towards data of the ethoxylation products.

\section{RESULT AND DISCUSSION}

Ethoxylation of glycerol mono oleate (GMO) was recorded in Table 1 . The reaction was kept constant for 5 hours with the same molar ratio. Run 1 was performed at $120^{\circ} \mathrm{C}, \mathrm{KOH} 1 \%$, run 2 at $180^{\circ} \mathrm{C}$, $\mathrm{KOH} 1 \%$, and run 3 at $180^{\circ} \mathrm{C}, \mathrm{KOH} 5 \%$.

Table 1 shows the density and viscosity of the glyceril products. The density increased with the increase of temperature. This indicates that the ethoxylation occurred with the increase of molecular weight. The highest was recorded at run 3 with $0.9684 \mathrm{~g} / \mathrm{cm}^{3}$. The level of viscosity was also increased with the increase of pressure and catalyst concentration. It can be seen that GE with viscosity of $67.04 \mathrm{cp}$ increased after ethoxylation and the product gave viscosity of $76.59 \mathrm{cp}, 88.16 \mathrm{cp}$, and $253.64 \mathrm{cp}$.

Acid and ester value of GE ethoxylate can be observed in Figure 2. It can be seen that a decrease of acid value occurs from run 1 to run 3 . The decrease was due to the presence of $\mathrm{KOH}$ in the reactor. The free fatty acid in the starting GE reacts with $\mathrm{KOH}$ yielding a metal salt and saponification. It was also caused by the increase of reaction temperature. At run 1 and 2, an amount of $1 \%$ of $\mathrm{KOH}$ was used and yielded 22.94 and 19.5 of acid value. Meanwhile at run 3 where $5 \% \mathrm{KOH}$ was applied, a drop of acid value as much as 12.35 was observed.

Ester value was also measured and a decrease can be seen at run 1 and 2. The decrease was 140.5 and 144.05 , respectively. In contrast, an increase was observed in run 3 with 105.95 . This is caused by the use of $5 \% \mathrm{KOH}$. The large number of catalyst yields an alkaline condition which produces saponification in the system and the ester value went down. 
Reaktor, Vol. 12 No. 2, Desember 2008, Hal. 102-106

Table 1. Density and viscosity of GMO and product of ethoxylation

\begin{tabular}{ccccccc}
\hline Run & Time $(\mathrm{h})$ & Temperature $\left({ }^{\circ} \mathrm{C}\right)$ & GMO:EO (mol) & Catalyst $(\%)$ & $\rho\left(40^{\circ} \mathrm{C}\right)$ & $\eta\left(40^{\circ} \mathrm{C}\right)$ \\
\hline GMO & - & - & - & - & $0.9392 \mathrm{~g} / \mathrm{cm}^{3}$ & $67.04 \mathrm{cp}$ \\
1 & 5 & 120 & $1: 1$ & 1 & $0.9418 \mathrm{~g} / \mathrm{cm}^{3}$ & $76.59 \mathrm{cp}$ \\
2 & 5 & 180 & $1: 1$ & 1 & $0.9464 \mathrm{~g} / \mathrm{cm}^{3}$ & $88.16 \mathrm{cp}$ \\
3 & 5 & 180 & $1: 1$ & 5 & $0.9684 \mathrm{~g} / \mathrm{cm}^{3}$ & $253.64 \mathrm{cp}$ \\
\hline
\end{tabular}

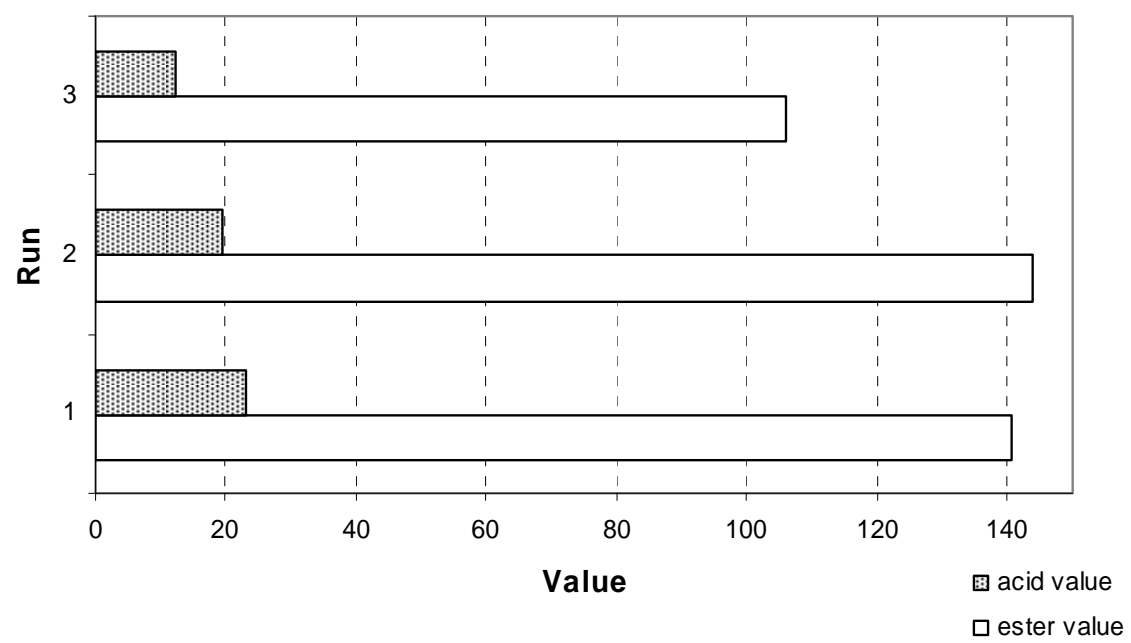

Figure 2. Acid value and ester value of glyceril mono oleate ethoxylated products
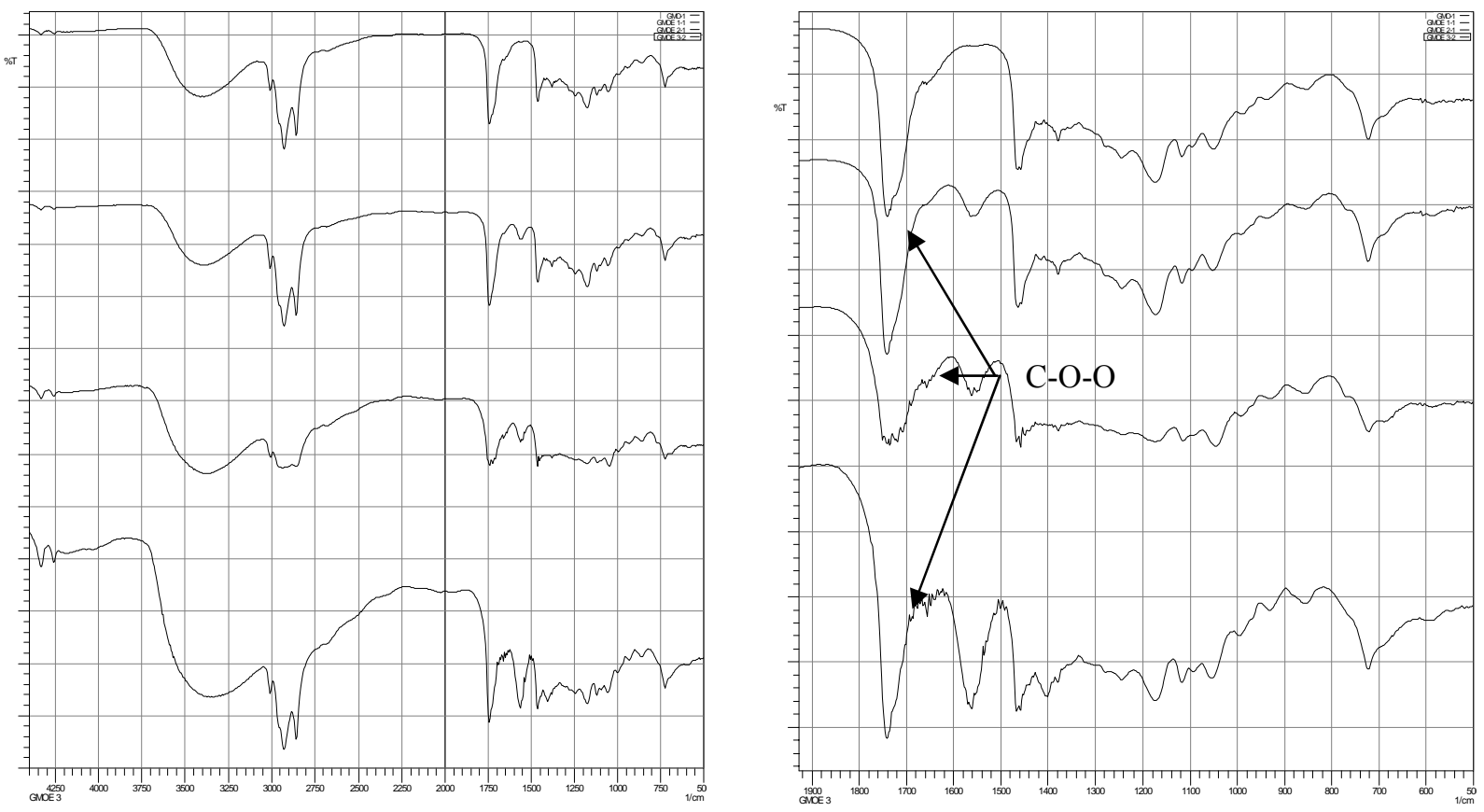

Figure 3. FTIR analysis of the ethoxylation products at wavelengths: (i) $500-4000 \mathrm{~cm}^{-1}$ (ii) $500-2000 \mathrm{~cm}^{-1}$ from top to bottom: glyceril esters, run 1, run 2, and run 3 . 
Fourier Transform Infrared (FTIR) analysis was performed to see the changes in functional groups of the starting material and product. It can be observed in fig. 3 that a new peak was formed at $1570 \mathrm{~cm}^{-1}$. This peak indicated the $\mathrm{C}-\mathrm{O}-\mathrm{O}$ binding which was formed due to ethoxylation. At run 1 the intensity was quite weak, but at run 2 and 3 increase of intensity occurred indicating that the ethoxylation was greater. This is not seen in the starting material. Further analysis of the products was performed by C-NMR analysis.

The degree of polymerization was determined by ${ }^{13} \mathrm{C}$ - Nuclear Magnetic Resonance $\left({ }^{13} \mathrm{C}-\mathrm{NMR}\right)$. The addition of two carbon atoms in the structure indicates that one ethylene oxide molecule was inserted between the carbonyl group in the glycerol mono oleate structure. The result of analysis is shown in Figure 4.

Figure 4 shows the overlay of C-NMR analysis of glycerol mono oleate and run 2. Six new peaks were observed with chemical shifts $(\delta)$ $61.3385 ; 61.9108 ; 62.5117 ; 63.8566 ; 66.0982$; and 72.6127. This indicates that three molecules of ethylene oxide was inserted in the structure and yielded product with degree of polymerization $n=3$.

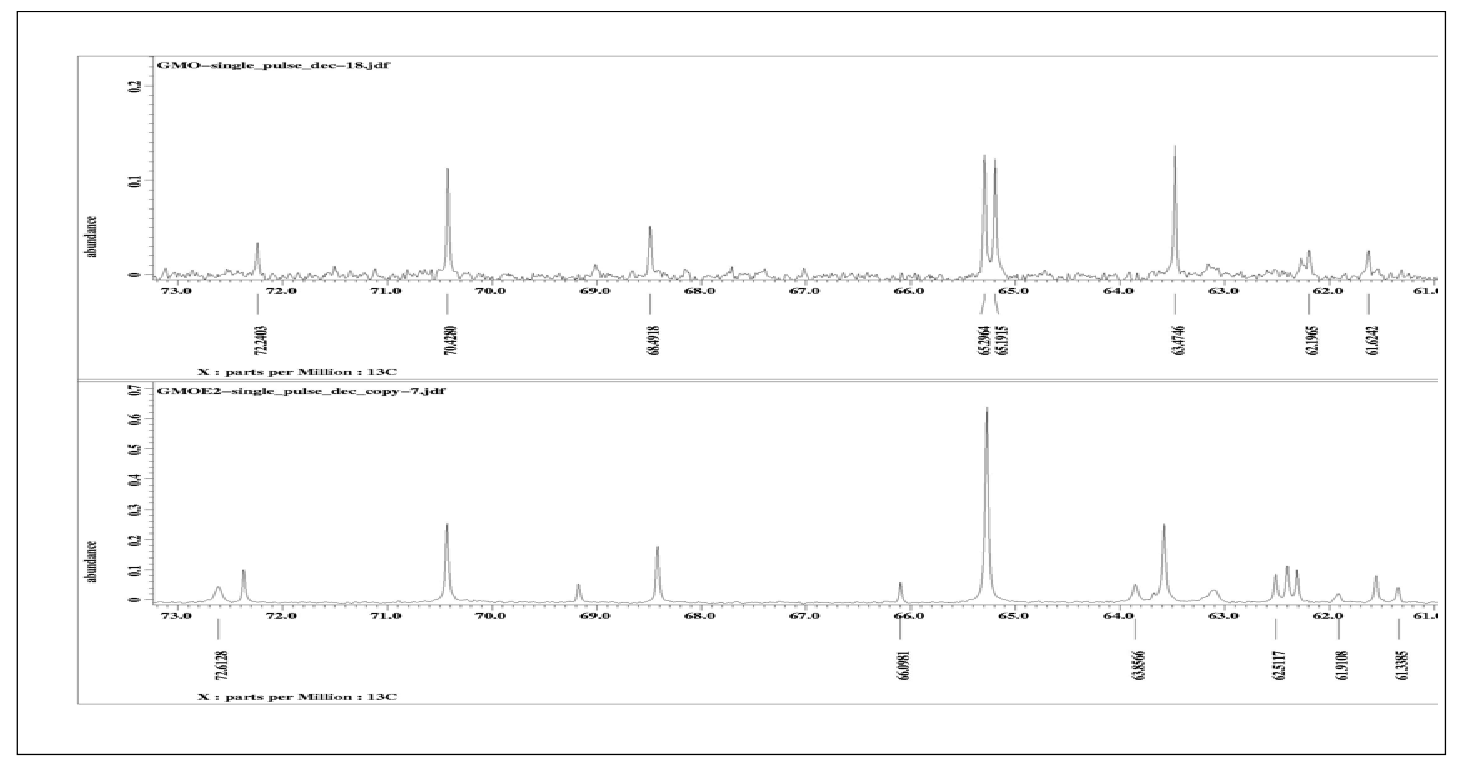

Figure $4 .{ }^{13} \mathrm{C}-\mathrm{NMR}$ analysis of Run 2

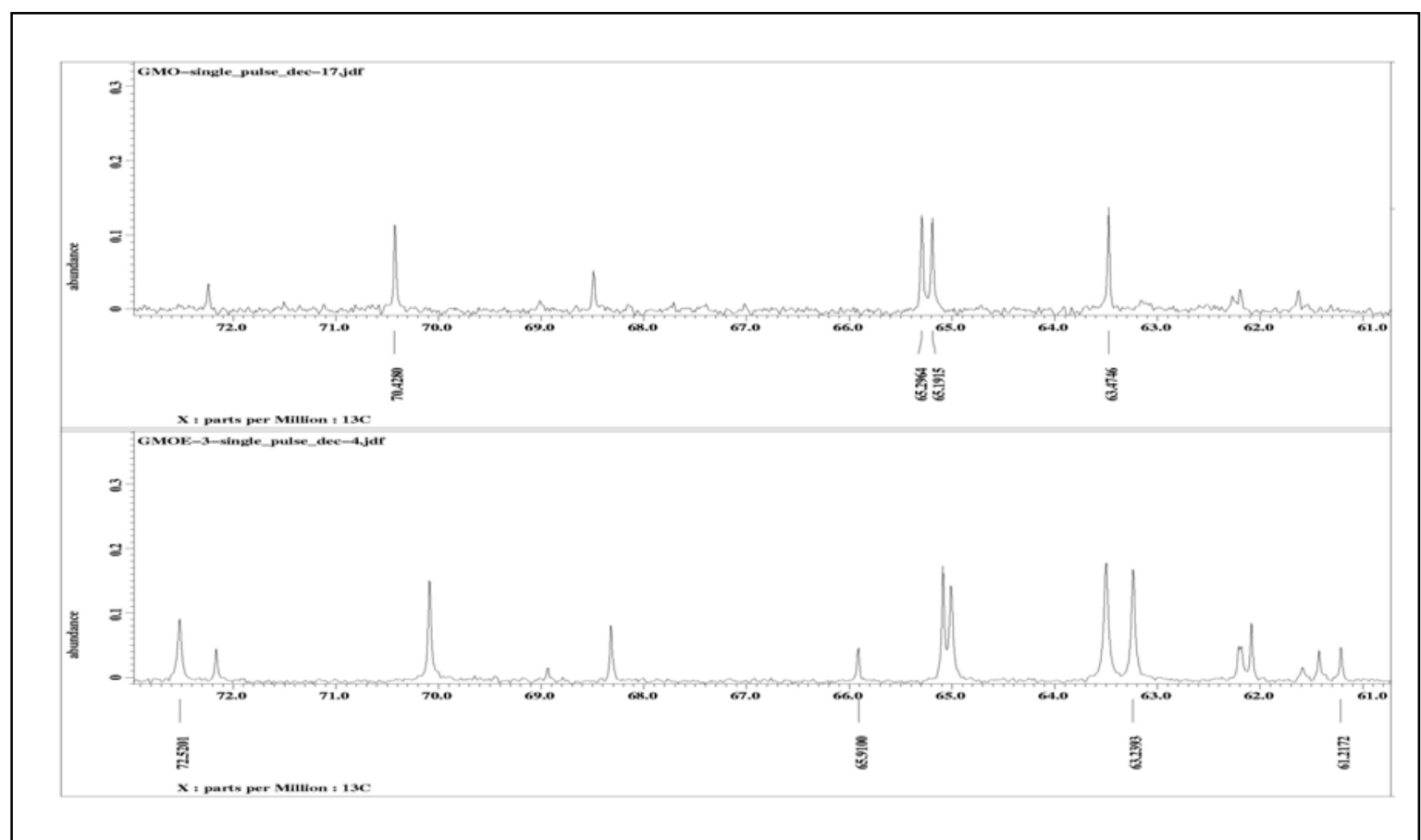

Figure. $5{ }^{3} \mathrm{C}-\mathrm{NMR}$ analysis of run 3 
The analysis of run 3 is given in Figure 5. New peaks were also observed with chemical shifts $(\delta)$ $61.2172 ; 63.2393 ; 65.9100$; and 72.5201. The degree of polymerization was slightly lower in run 3 with $n=2$. At run 1 , there were no significant changes therefore the result was not given. It can be predicted that the ethoxylation occurred but not as much in run 2 and run 3 .

\section{CONCLUSION}

Ethoxylation of glycerol mono oleate from palm oil can undergo in a bubble column reactor at temperature $120-180^{\circ} \mathrm{C}, 5$ hours, and molar ratio GE: $\mathrm{EO}=1: 1$. The products had higher level of density and viscosity than that of the starting material glycerol mono oleate. The structure was predicted by FTIR analysis with the formation of $\mathrm{C}-\mathrm{O}-\mathrm{O}$ functional group at $1570 \mathrm{~cm}^{-1}$. The degree of polymerization differed with the ethoxylation condition identified by ${ }^{13} \mathrm{C}-\mathrm{NMR}$ analysis. In this research an ethoxylate product with degree of polymerization $n=2$ and $n=3$ was yielded.

\section{REFERENCES}

Breindel, K., Broadbent, Ronald, W., Wiggins, Michael, S., Natele, and Marcie, (2001), Branced polymeric surfactant reaction products, methods for preparation and use therefore, USP20010027227.

Di Serio, Di Martino, S., and Santecesaria, E., (1994), Kinetics of fatty acids polyethoxylation, Ind. Eng. Chem. Res, 33, 509-514

Di Serio, M., Vairo, G., Lenggo, P., Fillipone, F., and Santacesaria, E., (1996), Kinetics of ethoxylation and propoxylation of 1- and 2-octanol catalyzed by $\mathrm{KOH}$, Ind. Eng. Chem. Res., 35, 3848.

Hama, I., Okamoto, T., Hidai, E., and Yamada, K., (1997), Direct ethoxylation of fatty methyl ester over Al-Mg composite oxide catalyst, JAOCS, vol. 74, no. 1

Hreczuch, W., (2002), Temperature-related reaction kinetics and product composition of ethoxylated fatty acid methyl esters, J. Chem. Technol. Biotechnol, 77: 511-516.

Singh, M., (2006), Polymeric surfactant, USP20060135639. 